Atmos. Chem. Phys., 10, 5991-5997, 2010

www.atmos-chem-phys.net/10/5991/2010/

doi:10.5194/acp-10-5991-2010

(C) Author(s) 2010. CC Attribution 3.0 License.

\title{
CityFlux perfluorocarbon tracer experiments
}

\author{
F. K. Petersson ${ }^{1, *}$, D. Martin ${ }^{1}$, I. R. White ${ }^{1}$, S. J. Henshaw ${ }^{1}$, G. Nickless ${ }^{1}$, I. Longley ${ }^{2, * *}$, C. J. Percival ${ }^{2}$, M. Gallagher ${ }^{2}$, \\ and D. E. Shallcross ${ }^{1}$ \\ ${ }^{1}$ School of Chemistry, University of Bristol, Bristol, UK \\ ${ }^{2}$ SEAS, University of Manchester, Manchester, UK \\ *now at: Ionicon Analytik Gesellschaft mbH, Innsbruck, Austria \\ ${ }^{* *}$ now at: National Institute of Water and Atmospheric Research, Auckland, New Zealand
}

Received: 30 September 2009 - Published in Atmos. Chem. Phys. Discuss.: 5 January 2010

Revised: 17 May 2010 - Accepted: 28 May 2010 - Published: 5 July 2010

\begin{abstract}
In June 2006, two perfluorocarbon tracer experiments were conducted in central Manchester UK as part of the CityFlux campaign. The main aim was to investigate vertical dispersion in an urban area during convective conditions, but dispersion mechanisms within the street network were also studied. Paired receptors were used in most cases where one receptor was located at ground level and one at roof level. One receptor was located on the roof of Portland Tower which is an $80 \mathrm{~m}$ high building in central Manchester. Source receptor distances in the two experiments varied between 120 and $600 \mathrm{~m}$.

The results reveal that maximum concentration was sometimes found at roof level rather than at ground level implying the effectiveness of convective forces on dispersion. The degree of vertical dispersion was found to be dependent on source receptor distance as well as on building height in proximity to the release site.

Evidence of flow channelling in a street canyon was also found. Both a Gaussian profile and a street network model were applied and the results show that the urban topography may lead to highly effective flow channelling which therefore may be a very important dispersion mechanism should the right meteorological conditions prevail.

The experimental results from this campaign have also been compared with a simple urban dispersion model that was developed during the DAPPLE framework and show good agreement with this.
\end{abstract}

Correspondence to: D. E. Shallcross

(d.e.shallcross@bristol.ac.uk)
The results presented here are some of the first published regarding vertical dispersion. More tracer experiments are needed in order to further characterise vertical concentration profiles and their dependence on, for instance, atmospheric stability. The impact of urban topography on pollutant dispersion is important to focus on in future tracer experiments in order to improve performance of models as well as for our understanding of the relationship between air quality and public health.

\section{Introduction}

As part of the CityFlux campaign (Langford et al., 2009; C. L Martin. et al., 2009) two perfluorocarbon tracer experiments were carried out. These experiments, in conjunction with the REPARTEE perflurocarbon tracer experiments are part of the recent extensive work conducted regarding vertical dispersion in urban areas using perfluorocarbon tracers (D. Martin et al., 2009). In contrast to the REPARTEE tracer experiments that were conducted during neutral atmospheric stability, the CityFlux experiments took place during convective days.

Vertical dispersion has been a neglected area of research. A few tracer experiments were carried out in the mid twentieth century in mostly rural areas using more exotic tracers such as smoke, aniline vapour and zinc cadmium sulphide (Sutton, 1947; Barad and Fuquay, 1961; Thompson, 1965, 1966).

Published by Copernicus Publications on behalf of the European Geosciences Union. 
In recent years a few articles have been published presenting results on vertical concentration profiles. Uniform vertical profiles in street canyons have been observed for source receptor distances of $700 \mathrm{~m}$ (Rotach et al., 2004) and $1 \mathrm{~km}$ (Cooke et al., 2000). In these experiments, receptors were placed on the roof of buildings with a maximum height of $30 \mathrm{~m}$.

The most extensive campaign undertaken so far regarding vertical dispersion took place in Oklahoma City during the Joint URBAN 2003 campaign (Flaherty et al., 2007). 7 receptors were placed on a crane between 10 and $75 \mathrm{~m}$ above the ground at a distance of $1 \mathrm{~km}$ away from the release site. Daytime experiments revealed that the plume was relatively well mixed where the lowest concentration returned was typically within $50 \%$ of the maximum concentration in the vertical profile. However, maximum concentration was returned more often in the lower half of the profile. A slightly less uniform profile was seen when night time experiments were undertaken. One experiment was also carried out where the source receptor distance was only $500 \mathrm{~m}$. Here, a distinct vertical concentration profile was found where the maximum concentration returned was closer to the ground than for the $1 \mathrm{~km}$ experiments.

Wind tunnel studies have previously been made in order to investigate vertical dispersion. Usually, the shape of the vertical concentration profile is somewhere in between exponential and Gaussian as reviewed by Britter el al. (2003). Previous wind tunnel measurements have though focused on neutral conditions and not convective situations as is the case for these field measurements.

This article also presents results concerning the effect of channelling of flow in street canyons. A great deal of effort has been invested recently into understanding wind flows in street canyons and in particular its dependence on the aboveroof wind flow (e.g. Arnold et al., 2004; Dobre et al., 2005; Wood et al., 2009). A street network model has been tested with the dataset here and reveals promise in order to understand the close range dispersion in urban areas. In this model a plume encountering an intersection is divided up into two parts ( $\mathrm{R}$ and 1-R) depending on the street alignment to the above-roof wind direction. This division of the plume occurs at every intersection downwind of the source. $\mathrm{R}$ can therefore both (i) be calculated from the relationship between wind angle and street network and (ii) be experimentally determined based on the ratio of the results from various receptors.

The results presented in this article will also be compared with "the simple correlation for pollutant dispersion in the local environment" model that was developed as part of the DAPPLE framework (Neophytou and Britter, 2004). In this model the maximum concentration decays away with distance squared according to

$$
\frac{C_{\max } U}{Q}=\frac{K}{x^{2}}
$$

where $C_{\max }$ is the maximum concentration downwind of a point source with a release rate $(Q), U$ is the wind speed, $x$ the source receptor distance, $K$ which is dependent on urban morphology parameters such as the building frontal area $\left(\lambda_{f}\right)$ and the building plan area $\left(\lambda_{p}\right)$. The structure of the simple correlation model can be seen as a simplification of the Gaussian Plume formulation but here the concentration decay varies with the inverse square of the source receptor distance.

In Eq. (2) each term has been non-dimensionalised using $H_{b}$ which is the average building height:

$$
\frac{C_{\max } U H_{b}^{2}}{Q}=K \frac{H_{b}^{2}}{x^{2}}
$$

Based on the results from the DAPPLE work a $K$ of 10 or 20 was proposed to model maximum concentration following a release. This was proposed based on both experimental data from the DAPPLE area in central London as well as an investigation into the results from the field experiments undertaken in St. Louis, Salt Lake City and Birmingham by other research groups. The inverse square dependency on distance was also supported with wind tunnel experiments undertaken as part of the DAPPLE framework. The source receptor distances for all these were no longer than $10 \mathrm{~km}$. Based on the results from the Joint URBAN 2003 experiments conducted in Oklahoma City the results showed that $K$ was closer to 3 for daytime experiments and $K$ close to 10 for nighttime experiments (Hanna et al., 2007). The need to evaluate this model with an experimental dataset retrieved from other cities exists therefore in order to see what range $K$ is in and what parameters $K$ is dependent upon.

\section{Experimental}

The perfluorocarbon tracer release was made from pressurized cans containing 0.61 mole \% perfluoromethylcyclopentane (PMCP). A pressure transducer (Keller UK Ltd., Dorchester, UK) measured the pressure drop in the system and hence the release rate. Sampling was carried out using Universal sampling pumps (SKC limited, Dorset, United Kingdom) or in-house built sampling modules and Tedlar bags (SKC limited, Dorset, United Kingdom). Analytical determination of perfluorocarbons was made by ADS-GC-NICIMS. ADS is an abbreviation for Adsorption Desorption System where the perfluorocarbons are preconcentrated on a Carboxen based microtrap. A Carbograph PLOT capillary column and a temperature program separate all perfluorocarbons from each other including all six isomers of pefluorodimethylcyclohexane (PDMCH). The Mass Spectormeter is run in NICI (Negative Ion Chemical Ionization) mode which facilitates for highly sensitive determination. Atmospheric background perfluorocarbon mixing ratios in the single digit ppqv range are measureable. For a complete 
description of experimental methods see Wood et al. (2009), Shallcross et al. (2009) and Simmonds et al. (2002).

\section{First CityFlux perfluorocarbon tracer experiment}

The experimental area in central Manchester, UK, has previously been characterized (Langford et al., 2009; C. L. Martin et al., 2009). Wind measurements and one receptor was located at the top of Portland Tower which is an $80 \mathrm{~m}$ high rectangular office block. Apart from Portland Tower, the experimental area (for both experiments conducted) can be described as intensively developed high density urban area with 2-5 storey, attached or very close-set buildings often of brick or stone, i.e. urban classification of 2 according to Oke's criteria (Oke, 2006).

PMCP was released between 01:30 and 01:40 p.m. at a constant rate of $1.680 \times 10^{-7} \mathrm{~kg} \mathrm{~s}^{-1}$ from position X in Fig. 1 . A ground level release was made from the south side of Princess Street. Sampling took place during the same time interval as the release, i.e. between 01:30 and 01:40 p.m., at receptors 1-10 in Fig. 1. A 3-D anemometer located at the top of Portland Tower recorded an average wind direction of $293^{\circ}$ from north and an average wind speed of $5.7 \mathrm{~m} \mathrm{~s}^{-1}$. The experiment was conducted during sunny conditions and the temperature was $18^{\circ} \mathrm{C}$.

The atmospheric background subtracted concentrations returned, normalised by the perfluorocarbon release rate, are shown in Table 1 and in Fig. 1. The average wind direction (green arrow in Fig. 1) reveals that there is a direct connection between the source site $(\mathrm{X})$ and Portland Tower and high perfluorocarbon tracer concentrations are found at the tower. Also tracer is found at receptor 4 and 5 but not at receptors $7-10$ which can be used to estimate the size of the plume.

\subsection{Vertical concentration profile}

The vertical concentration profile at Portland Tower reveals that the receptor at ground level (receptor 1) did not return the highest concentration but rather the receptor on the car park roof (receptor 3) slightly further away from the release site. The enhanced vertical dispersion can also be seen when comparing receptors 1 and 2. Receptor 2 at the top of Portland Tower returned a concentration slightly higher than that predicted by the Gaussian plume equation during stability class $C$, using Briggs' Interpolation Formulae, shown in Table 1. This is the class preferred since the urban environment tends to favour neutral stability (Britter and Hanna, 2003). The unstable atmospheric conditions encountered here have caused the plume to extend in the vertical direction and the majority of the plume is located above ground level about $350 \mathrm{~m}$ away from the source.

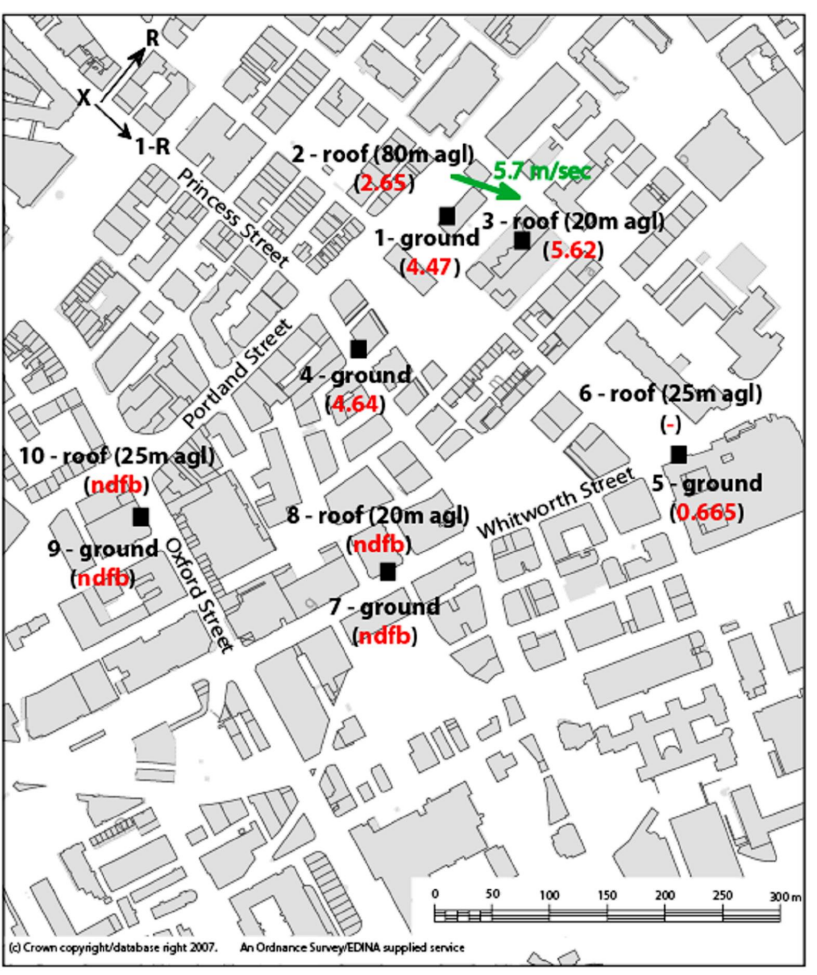

Fig. 1. First Cityflux perfluorocarbon tracer experiment including release position (X) and sampling locations (1-10) showing height above ground level and results obtained (concentration/release rate). "ndfb" = non-discernable from background, "-“ = failed sample. Average wind conditions during the experiment at Portland Tower $\left(5.7 \mathrm{~m} \mathrm{~s}^{-1}, 293^{\circ}\right.$ from North) are shown in green.

\subsection{Street channelling effect}

The results from receptor 1 and 4 (both at ground level) is used to evaluate the channelling effect. Both receptors returned similar amounts of tracer and the source receptor distances are similar but the source receptor angles are not. Receptor 1 is almost on the plume centreline based on the recorded wind direction at Portland Tower whereas receptor 4 is about $22^{\circ}$ away. These results indicate street channelling along Princess Street showing the effect the urban topography enforces on wind flows and dispersion.

An attempt to quantify the channelling effect has been made by comparing this particular urban area with a flat terrain in a rural area where a Gaussian profile is assumed to approximate the lateral distribution of a plume. The concentration returned at receptor 4 would be $14 \%$ of that returned at receptor 1 when applying a Gaussian distribution with a plume centreline along the average wind direction recorded. Since the concentration returned for the two receptors are almost identical the urban topography has increased the tracer amounts at receptor 4 by at least a factor of 7 . The profound difference of dispersion in urban areas compared with rural areas is therefore demonstrated here. 
Table 1. Results (10 min averages) from the first CityFlux Perfluorocarbon Tracer Experiment. The sigma parameters were calculated according to $\sigma_{y}=0.22 \mathrm{x}(1+0.0004 \mathrm{x})^{-1 / 2}$ and $\sigma_{z}=0.20 \mathrm{x}$ where $\mathrm{x}$ is the source receptor distance.

\begin{tabular}{cccc}
\hline $\begin{array}{c}\text { Receptor } \\
\text { number }\end{array}$ & $\begin{array}{c}\text { Atmospheric background } \\
\text { subtracted concentration/release } \\
\text { rate }\left(10^{-6} \mathrm{~s} \mathrm{~m}^{-3}\right)\end{array}$ & $\begin{array}{c}\text { Concentration/release } \\
\text { rate relative } \\
\text { to receptor 1 }\end{array}$ & $\begin{array}{c}\text { Gaussian plume } \\
\text { equation relative } \\
\text { to receptor } 1\end{array}$ \\
\hline 1 & 4.47 & 1.00 & 1.00 \\
2 & 2.65 & 0.59 & 0.49 \\
3 & 5.62 & 1.26 & 0.72 \\
4 & 4.64 & 1.04 & 0.14 \\
5 & 0.665 & 0.15 & 0.30 \\
6 & - & - & 0.30 \\
7 & ndfb & N/A & 0.19 \\
8 & ndfb & N/A & 0.19 \\
9 & ndfb & N/A & 0 \\
10 & ndfb & N/A & 0 \\
\hline
\end{tabular}

"ndfb" = non-discernable from background, "-“" = failed sample.

Another analysis in order to investigate the channelling effect is to compare the experimental results with the aboveroof wind direction recorded relative to street geometry. In this analysis, the plume is assumed to split up into two components ( $\mathrm{R}$ and $1-\mathrm{R}$ ) every time it encounters an intersection (Fig. 1). If all components are added together this would imply a "concentration" at receptor 4 of $(1-\mathrm{R})^{5}$ and at receptor 1 of $5 R(1-R)^{4}$. By equating these two equations $R$ was determined to be 0.17 . By dividing up the wind direction obtained at Portland Tower into vectors aligned as the street network $\mathrm{R}$ was calculated to 0.19 , a remarkably close agreement. Street geometry and above roof wind direction can therefore explain the concentration profile found here within the error of the measurements. The conclusion is therefore that the effect of street channelling has played a major role in plume dispersion.

\section{Second CityFlux perfluorocarbon tracer experiment}

During the tracer experiment carried out on 27 June 2006, PMCP was released between 01:00 and 01:26 p.m. at a constant rate of $1.594 \times 10^{-7} \mathrm{~kg} \mathrm{~s}^{-1}$ from position $\mathrm{Y}$ in Fig. 2 . The release was made from ground level from the south side of Oxford Street. Sampling was made at receptors 1-2 and 512 in Fig. 2. During the $26 \mathrm{~min}$ release three samples $(8 \mathrm{~min}$ each) were taken at each receptor sequentially, including a one minute gap in between every sample. No wind measurements from Portland Tower were available this day but the UK Met Office's weather station at Woodford airport reported an hourly (13:00-14:00) average wind direction of $200^{\circ}$ and an average wind speed of $3 \mathrm{~m} \mathrm{~s}^{-1}$. The experiment was conducted during sunny conditions.

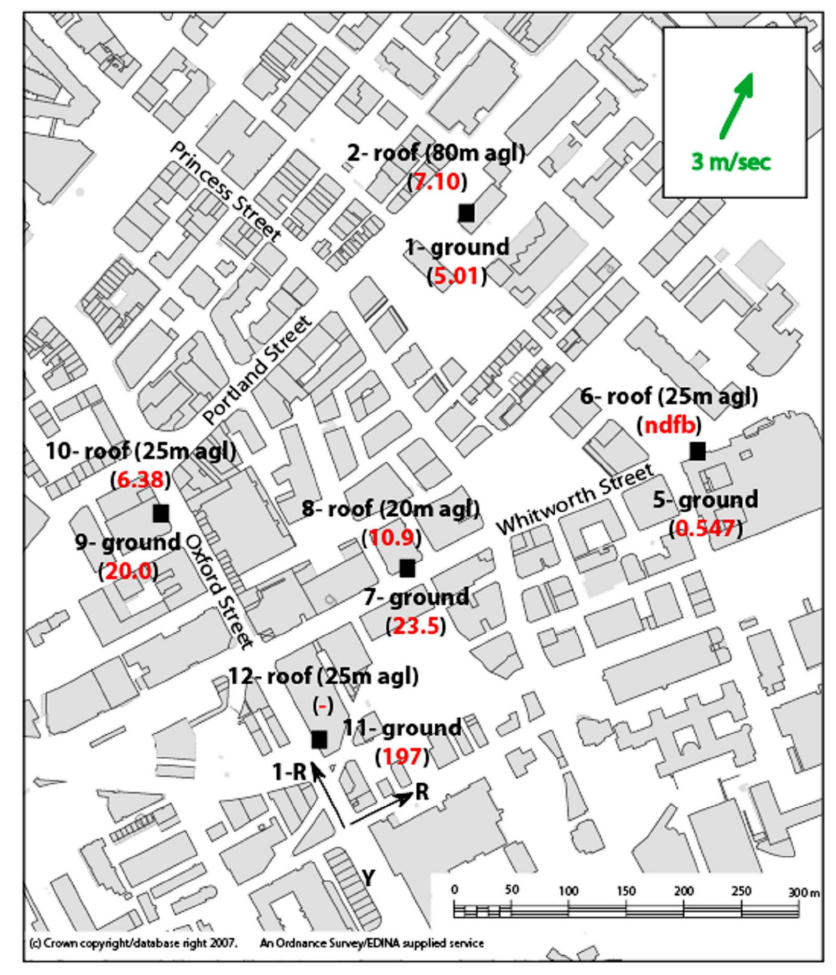

Fig. 2. Second Cityflux perfluorocarbon tracer experiment including release position ( $\mathrm{Y}$ ) and sampling locations (1-2 and 5-12) showing height above ground level and results obtained (concentration/release rate) from the third sampling period. "ndfb" = nondiscernable from background, “-“" = failed sample. One hour average wind conditions at Woodford Airport are shown in green $(3 \mathrm{~m}$ $\mathrm{s}^{-1}, 200^{\circ}$ from North). 
Table 2. Results (8 min averages) from the second CityFlux Perfluorocarbon Tracer Experiment.

\begin{tabular}{cccc}
\hline & \multicolumn{3}{c}{$\begin{array}{c}\text { Atmospheric background subtracted } \\
\text { concentration/release rate }\left(10^{-6} \mathrm{~s} \mathrm{~m}^{-3}\right)\end{array}$} \\
\cline { 2 - 4 } Receptor & Sample 1 & Sample 2 & Sample 3 \\
number & $(13: 00: 00-13: 08: 00)$ & $(13: 09: 00-13: 17: 00)$ & $(13: 18: 00-13: 26: 00)$ \\
\hline 1 & ndfb & ndfb & 5.01 \\
2 & ndfb & ndfb & 7.10 \\
5 & ndfb & 0.406 & 0.547 \\
6 & 1.26 & 0.522 & ndfb \\
7 & ndfb & 0.447 & 23.5 \\
8 & 0.422 & 0.903 & 10.9 \\
9 & 0.770 & 1.07 & 20.0 \\
10 & ndfb & ndfb & 6.38 \\
11 & 6.72 & 0.935 & 197 \\
12 & 0.682 & 5.17 & - \\
\hline
\end{tabular}

"ndfb" = non-discernable from background, "-“" = failed sample.

The atmospheric background subtracted concentrations returned, normalised by the perfluorocarbon release rate, are seen in Table 2 and Fig. 2 displays the results from the third sample. An elevation above atmospheric background concentrations are seen at all receptors. During the first and second sample only small perfluorocarbon tracer amounts were found at the sampling sites. However, during the third samples clear vertical concentration profiles were found at several of the ground/roof paired receptor sites. It is likely a shift in wind direction caused the difference in results between the first two and the third sampling period. The benefit of "local" meteorological measurments is here obvious but due to access restrictions at Portland Tower during the second experiment only the reported meteorological data from Woodford airport is available.

\subsection{Vertical concentration profiles}

During the first two samples only small amounts of the tracer reached any of the receptors. The concentrations returned for the receptors closest to the release site (11 and 12) are highly variable; in the first sample the ground level receptor returned the highest concentration and in the second the roof level receptor. This shows the intermittency of the dispersion of individual tracer parcels that arise during low wind speed conditions where it may be difficult to envisage a plume due to turbulence being the main mode of transportation rather than average wind speed. Therefore the tracer could be seen to consist of "blobs" of air indicating their highly variable temporal and spatial scale (D. Martin et al., 2008).

During the time period when the third sample was taken, advection of the plume occurred towards most of the receptors. The paired receptors (7/8 and 9/10) both show a vertical gradient in each respective street canyon. For the paired receptors 7 and 8 the ratio ground to roof is $2: 1$ and for receptors 9 and 10 the corresponding ratio is $3: 1$. The difference in the results may be attributed to difference in receptor height.

Although the source receptor distances for receptors $7 / 8$ and $9 / 10$ are similar to the source receptor distance for receptors 1 and 3 in the first experiment, the maximum concentration is found at ground level in the second experiment and not at roof level as in the first experiment. The difference in results can be explained by the height of the buildings in close proximity to the two release sites. The buildings located on the northern side of Princess Street close to the release site in experiment 1 are generally 2 storey (except one 5 storey building). This would make it fairly easy for an above roof component of the plume to be formed thus resulting in higher concentrations returned at roof level rather than at ground level. It is more difficult for an above roof level component of the plume to be formed early on during the second experiment. Here, the buildings on the northern side of Oxford Street close to the release site range between 4 and 6 storeys, that effectively trap the plume within the street canyon.

At Portland Tower the vertical profile is inversed; the roof top receptor returns a concentration $42 \%$ higher than the ground level receptor implying the importance of enhanced vertical dispersion during convective situations. These results, in conjunction with the profile obtained at Portland Tower during the first experiment, shows that a Gaussian profile is not a suitable description of dispersion during convective conditions since the maximum concentration was not found at ground level. The question of whether a vertical Gaussian profile was suitable was also raised in the recent REPARTEE campaign investigating vertical dispersion during neutral conditions. Although approximate Gaussian 


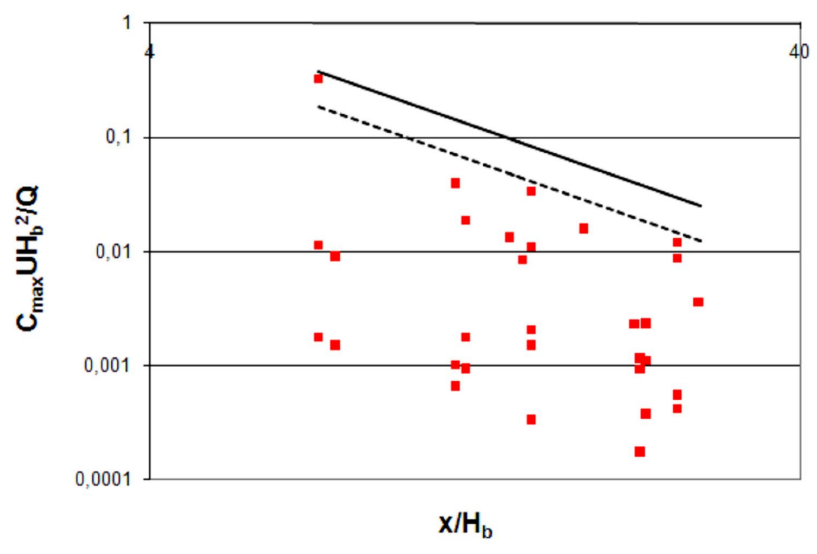

Fig. 3. The results from both CityFlux experiments compared to the Simple Correlation model. Dotted line represents $K=10$ and solid line $K=20$ in the simple correlation model.

vertical profiles were found, the profile was also found to be dependent on the source receptor distance (measured over 460-1370 m; D. Martin et al., 2009).

\subsection{Street network model}

The street network model has been tested against the results obtained from the second experiment for receptors 7 and 9 and for the third sample taken. The resulting component at receptor 7 was determined to $4 \mathrm{R}(1-\mathrm{R})^{3}$ and at receptor $9(1-$ $\mathrm{R})^{3}$. By taking into account the almost $20 \%$ higher concentration returned at receptor $7, \mathrm{R}$ was determined to be 0.3 . $\mathrm{R}$ calculated based from the wind direction obtained from Woodford airport and the street alignment is 0.52 . The difference between the two values of $\mathrm{R}$ is larger in experiment 2 than in experiment 1 . However, the wind data is taken from Woodford and therefore the agreement is pretty reasonable, in keeping with wind analysis performed by Scaperdas and Colvile (1999). The model comparison made for the first experiment is very encouraging and suggests that "local" meteorological measurements are important in such an analysis.

\section{Simple correlation model}

Figure 3 displays the results from both experiments compared with the simple correlation model. The wind speed from Woodford airport for both experiments have been used in this analysis. During the first experiment Woodford airport reported a wind speed of $5.1 \mathrm{~m} \mathrm{~s}^{-1}$ (compared to $5.7 \mathrm{~m} \mathrm{~s}^{-1}$ measured on top of Portland Tower). Figure 3 reveals that all experimental data points bar one are below the dotted line representing $K=10$. One data point is located in between 10 and 20 in the very near field range which shows the large variability that may arise at close range. In this particular case the receptor returning high perfluorocarbon tracer concentration was located in the same street canyon as the release site which may give rise to very high tracer concentrations due to trapping in the street canyon. The same formulation and estimation of $K$, in a similar manner to the results from the DAPPLE campaign in central London, UK (Wood et al., 2009), can therefore successfully explain the maximum concentration found during these experiments undertaken in central Manchester using wind speed measurements obtained from a nearby airport.

The simple correlation model has here been evaluated over distances up to $600 \mathrm{~m}$. The range of validity of this model has been under scrutiny and a suggested limit of 50 times the average building height was proposed during the DAPPLE framework. At longer distances the decay rate is expected to be reduced from an inverse square to inverse 1.5 or inverse 1.75. No sign of this is seen here but the source receptor distances are too short in order to investigate that (maximum source receptor distance is $600 \mathrm{~m}$ for these experiments).

\section{Conclusions}

Vertical concentration profiles during convective conditions have been presented. Convective forces play an important part in pollutant dispersion where maximum concentration was sometimes encountered on the roof of a building or tower rather than on the ground. The possibility of formation of an above-roof component of the tracer released is important in evaluation of vertical concentration profiles and the aboveroof component is dependent on the building height close to the release site.

The importance of street channelling was also shown and again reflects the importance urban topography exercise on dispersion. A simple street network model could explain the dispersion pattern found in the first experiment where a relatively uniform street network is seen. The simple correlation model developed during the DAPPLE work has been accurately used to model the maximum concentration in these experiments.

Acknowledgements. FKP, IRW and SJH thank Marie Curie EST (BREATHE), Bristol ChemLabS and EPSRC, respectively for funding for a studentship.

Edited by: R. M. Harrison 


\section{References}

Arnold, S. J., ApSimon, H., Barlow, J., Belcher, S., Bell, M., Boddy, J. W., Britter, R., Cheng, R., Clark, R., Colville, R. N., Dimitoulopolou, S., Dobre, A., Greally, B., Kaur, S., Knights, A., Lawton, T, Makepeace, A., Martin, D., Neophytou, M., Neville, S., Niewenhuilsen, M., Nickless, G., Price, C. S., Robins, A., Shallcross, D., Simmonds, P., Smalley, R. J., Tate, J., Tomlin, A. S., Wang, H., and Walsh, P.: Introduction to the DAPPLE Air Pollution Project, Sci. Total Environ., 332, 139-153, 2004.

Barad, M. L. and Fuquay, J. J: The Green Glow Diffusion Program, Geophys. Res. Papers No 73, Vols I and II, Geophys Res. Dir., Bedford, Mass., 1961.

Britter, R. E. and Hanna, S. R.: Flow and Dispersion in Urban Areas, Annu. Rev. Fluid Mech., 35, 469-496, 2003.

Britter, R. E., Hanna, E. R., Briggs, G. A., and Robins, A.: Shortrange vertical dispersion from a ground level source in a turbulent boundary layer, Atmos. Environ., 37, 3885-3894, 2003.

Cooke, K. M., Di Sabatino, S., Simmonds, P. G., Nickless, G., Britter, R. E., and Caton, F.: Tracers and dispersion of gaseous pollutants in an urban area. Birmingham tracer experiments, Natural Environment Research Council, Technical report, Project Ref : GST/02/1974, 2000.

Dobre, A., Arnold, S. J., Smalley, R. J, Boddy, J. W. D., Barlow, J. F., Tomlin, A. S., and Belcher, S. E.: Flow field measurements in the proximity of an urban intersection in London, UK, Atmos. Environ., 39(26), 4647-4657, 2005.

Flaherty, J. E., Lamb, B., Allwine, K. J., and Allwine, E.: Vertical Tracer Concentration Profiles Measured during the Joint Urban 2003 Dispersion Study, J. Appl. Meteorol. Clim., 46, 2019-2037, 2007.

Langford, B., Davison, B., Nemitz, E., and Hewitt, C. N.: Mixing ratios and eddy covariance flux measurements of volatile organic compounds from an urban canopy (Manchester, UK), Atmos. Chem. Phys., 9, 1971-1987, doi:10.5194/acp-9-1971-2009, 2009.

Hanna, S., White, J., and Zhou, Y.: Observed winds, turbulence and dispersion in built-up downtown areas of Oklahoma City and Manhattan, Bound.-Lay. Meteorol., 125, 441-468, 2007.

Martin, C. L., Longley, I. D., Dorsey, J. R., Thomas, R. M., Gallagher, M. W., and Neimitz, E.: Ultrafine particle fluxes above four major European cities, Atmos. Environ., 43, 4714-4721, 2009.
Martin, D., Price, C. S., White, I. R., Nickless, G., Dobre, A., and Shallcross, D. E.: A study of pollutant concentration variability in an urban street under low wind speeds, Atmos. Sci. Lett., 9, 147-152, 2008.

Martin, D., Petersson, K. F., White, I. R., Henshaw, S. J., Nickless, G., Lovelock, A., Barlow, J. F., Dunbar, T., Wood, C. R., and Shallcross, D. E.: Tracer concentration profiles measured in central London as part of the REPARTEE campaign, Atmos. Chem. Phys. Discuss., 9, 25245-25274, doi:10.5194/acpd9-25245-2009, 2009.

Neophytou, M. K. and Britter, R. E.: A simple correlation for pollution dispersion predicted in urban areas. DAPPLE note 1 , available at: www.dapple.org.uk, 2004.

Oke, T. R.: Towards better scientific communication in urban climate, Theor. Appl. Climatol., 84, 179-190, 2006.

Rotach, M. W., Gryning, S.-E., Batchvarova, E., Christen, A., and Vogt, R.: Pollutant dispersion close to an urban surface - the BUBBLE tracer experiment, Meteorol. Atmos. Phys., 87, 39-56, 2004.

Scaperdas, A. and Colville R. N.: Assessing the representativeness of monitoring data from an urban intersection site in central London, UK, Atmos. Environ., 33 661-674, 1999.

Shallcross, D. E., Martin, D., Price, C. S., Nickless, G., White, I. R., Petersson, F., Britter, R. E., Neophytou, M. K., Tate, J. E., Tomlin, A. S., Barlow, J. F., and Robins, A.: Short range mobile urban dispersion experiments using an instrumented vehicle, Atmos. Sci. Lett., 10, 59-65, 2009.

Simmonds, P. G., O’Doherty, S., Nickless, G., Sturrock, G. A., Swaby, R., Knight, P., Ricketts, J.,Woffendin, G., and Smith, R.: Automated Gas Chromatograph/Mass Spectrometer for Routine Atmospheric Field Measurements of the CFC Replacement Compounds, the Hydrofluorocarbons and hydrochlorofluorocarbons, Anal. Chem., 67, 717-723, 1995.

Sutton, O. G.: The problem of diffusion in the lower atmosphere, Q. J. Roy. Meteor. Soc., 73, 257-281, 1947.

Thompson, N.: Short-range vertical diffusion in sable conditions, Q. J. Roy. Meteor. Soc., 91, 175-183, 1965.

Thompson, N.: The estimation of vertical diffusion over medium distances of travel, Q. J. Roy. Meteor. Soc., 92, 270-276, 1966.

Wood, C. R., Arnold, S. J., Balogun, A. A., Barlow, J. F., Belcher, S. E., Britter, R. E., Cheng, H., Dobre, A., Lingard, J. J. N., Martin, D., Neophytou, M. K., Petersson, F. K., Robins, A. G., Shallcross, D. E., Smalley, R. J., Tate, J. E., Tomlin, A. S., and White, I. R.: Dispersion experiments in central London: the 2007 DAPPLE project, B. Am. Meteorol. Soc., 90(7), 955-969, doi:10.1175/2009BAMS2638.1, 2009. 